\title{
FUNKCIONÁLIS ÉLELMISZEREK ELÓÁLLÍTÁSA, FORGALMAZÁSA ÉS FOGYASZTÁSA MAGYARORSZÁGON
}

\author{
- भी० \\ PRODUCTION, TRADE AND CONSUMPTION OF FUNCTIONAL FOODS IN HUNGARY \\ \$a. \\ BIACS, Péter Ákos

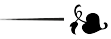 \\ Szent István Egyetem, Élelmiszer-tudományi Kar, Mikrobiológiai és Biotechnológiai Tanszék \\ (Szent Istuán University, Faculty of Food Science, Department for Microbiology and Biotechnology) \\ H-1118 Budapest, Villányi út 29-43 \\ e-mail: bia8440@mail.iif.hu
}

\begin{abstract}
gl
Functional food is a specific food which fulfills the original aim of being a nutrient and an energy-carrier, but promotes better health and well-being. During the last decades new and healthier foods were designed to reduce the risk of chronic illnesses and conditions such as cardiovascular diseases, osteoporosis, some cancers and obesity. However, functional foods are traditional foods expected to be consumed in the diet, but modified in such a way that promotes better health. In Hungary about $16 \%$ of the consumers are interested in buying functional foods for health improvements. Dairy products are most often the target products for reducing the risk of osteoporosis in the elderly and increasing gut function. In recent years the market of plant products, especially of fruits and vegetables was rapidly growing due to their high antioxidant capacity. Enhancement metabolism of polyphenols, and flavonoids formed in fruits and vegetables during traditional breeding and processing is not clarified yet and little is known about the effects of the extensive or intensive breeding and of the most economic harvesting time. The functional food science deals with the scientific substantiation of the influences of specific food components (biological active materials) as well as production and formulation of foods and food ingredients. Some of those components are obtained from natural sources, some others are artificial products of the organic synthesis in the industry. The term „functional foods” has never achieved an official definition, but most experts would agree on its benificially target functions in the body beyond adequate nutritional effects. Moderate consumption of vitamines and antioxidants in the diet carried in functional foods are belived to decrease the risk of chronic diseases. According to some market surveys the market of these designed foods is very large and rapidly expanding because of a growing interest among body-builders and other sportsmen with higher physical activities.
\end{abstract}

\section{BEVEZETÉS - INTRODUCTION}

\subsection{Az élelmiszerek funkciói - Functions of Foods}

Az élelem eredendő funkciója a tápanyag biztosítása, a szervezet folyamatos ellátása a szükséges energiahordozókkal. Ez képezi az élelmezésbiztonságot a társadalom szintjén. $\mathrm{Az}$ élelmiszerek egészségőrző, betegségmegelőző szerepe az utóbbi évtizedben vált lényegessé. Magyarországon a lakosság alig 16\%-a táplálkozik ma egészségtudatosan, válogatja meg mindennapi ételét, italát a táplálkozástudományi útmutatók szerint. Hazánk gazdaságföldrajzi, természeti adottságai miatt bősé- 
ges lehetőségünk van élelmiszer-termelésre, azonban nyersanyagaink viszonylag szegények jódban, vasban. Ezek pótlására olyan lehetőleg mindennap fogyasztott élelmiszerról kellett gondoskodni, melynek szintje megbízhatóan tartható és stabil: erre a jódozott konyhasó bizonyult megfelelő bevitelt biztosító megoldásnak, míg a vasra nézve inkább a gyógyszerekhez hasonló kapszula vált alkalmassá.

\subsection{Biológiailag aktív anyagok - Biologically Active Materials}

A biológiailag aktív anyagok felhalmozódása rendkívül eltérő lehet az általunk ismert és termesztett növényekben, tenyésztett állatokban. Az extenzív gazdálkodás körülményei között ugyanazon növényfajta termelése más fehérje-, szénhidrát- és zsírarányokkal írható le, mint az intenzív termesztésnél. Az extenzív termesztés többnyire elhúzódik, így a növények előállítása költségesebbé, időigényesebbé válik. Egyes Hungaricum növények, mint például a füszerpaprika piros színének mélyülése, a karotin-származékok felhalmozódása a leszedett növényi termés utóérlelésével, lassú szárításával érhető el (BIACS, 2006). Az intenzív gazdálkodás során a növény gyorsabban növekszik, több termést ad, de kevesebb biológiailag aktív anyagot tartalmaz. Az állatoknál megkülönböztetünk húshasznú és tejtermelésre alkalmasabb fajtákat, ez utóbbiaknál is elkülöníthető a sok tejet kevés zsírtartalommal, valamint a kevesebb, de zsírosabb tejet adó fajta, melynek tejét különböző termékekké (sajt, vaj) dolgozzák fel. Az említett tejtermékek mindegyike tartalmaz értékes ásványi anyagot (kalciumot), de a feldolgozás miatt különböző mennyiségben.

\section{ANYAg ÉS MÓDSZER - MATERIALS AND METHODS}

\subsection{Az élelmiszer-feldolgozás lehetôségei - \\ Food Processing Possibilities}

Az élelmiszeriparban a feldolgozás során további ásványi anyagot, vitamint adagolhatnak a nyersanyaghoz, így ezeket a termékben feldúsítják. A biológiailag aktív anyagokat, például a C-vitamint természetes forrásokból (zöldségnövények terméséből) nyerhetjük ki, de mesterségesen is előállíthatjuk (aszkorbinsavgyártás ipari szintézissel). A gyógyszerekhez hasonló formában (kapszulákban, pasztillákban, cseppekben) megjelenő termékeket étrend-kiegészítőknek (táplálékkiegészítőknek) nevezik, ezek nem élelmiszerek. Ügyelni kell az ilyen termékek fogyasztásánál arra, hogy a napi ajánlott mennyiség arányban legyen a kívánatos dózissal, porcióval, adaggal.

\subsection{A funkcionális élelmiszerek piaca - Market of Functional Foods}

Magyarországon a funkcionális élelmiszereknek több típusát megtaláljuk a piacon. Természetesen az lenne a legjobb, ha a magyar mezőgazdaságban azt a növényfajtát termesztenék, amelyik a szükséges ásványi anyagból, vitaminból a legtöbbet tartalmazza (BIACS és SZÁNTÓNÉ, 1985). Biológiailag aktív anyagok fogyasztásánál azonban célszerű táplálkozástudósokkal, orvosokkal megbeszélni az egyénre szabott, javasolható napi fogyasztást, nehogy túlzott mennyiség jusson szervezetünkbe. A biológiailag aktív anyagoknál többnyire feltüntetik a napi ajánlott mennyiséget, melynek betartása a fogyasztó feladata. A túlzott fogyasztás ugyanis kockázati tényezővé válhat bizonyos betegségek előfordulásánál.

\section{EREDMÉNYEK - RESUltS}

\subsection{A funkcionális élelmiszerek fogyasztása - Consumption of Functional Foods}

A szív- és érrendszeri betegségeknél ajánlás a zsiradékokban és konyhasóban szegény, rostanyagokban gazdag étrend betartása. Az 1990-es években az Egészségügyi Világszervezet (WHO - World Health Organization) felügyeletével és támogatásával hazánkban több intézményre és vállalatra kiterjedő kutatás-fejlesztés zajlott, annak érdekében, hogy a magyar mezőgazdaság és élelmiszeripar úgynevezett „szívbarát” élelmiszereket állítson elő és vigyen piacra. A programot a kanadai kormány egészségügyi 
intézményei is támogatták, a náluk indított hasonló projekt tapasztalatait sikerült menetközben értékelni és kicserélni. A fogyasztók ismereteinek bővítésére különböző kiadványokat, füzeteket és szórólapokat terjesztettek és a program lépéseit sajtótájékoztatókon tárták a nyilvánosság elé, valamint nemzetközi konferencián is előadásra került (HAJÓS és BIACS, 1999). A projekt keretében összesen 38 magyar terméket gyártottak le és nyerte el gondos tudományos ellenőrzés és zsűrizés után a „Szívbarát élelmiszer” címet és védjegyet. Ezek közül néhány még ma is piacképes és megtalálható a nagyáruházak polcain: fóleg étolajok és ásványvizek tartoznak ebbe a körbe. A program indítását követő években már csekély, de mérhető csökkenést lehetett érzékelni a szív- és érrendszeri betegségben történő elhalálozások számában. A program befejezését követően a magyar egészségügyi hatóságok inkább a közétkeztetés felé fordultak és beindították az un. sócsökkentő programot, mely főleg az alsó- és középfokú oktatási intézményekben ért el sikereket. A konyhasó-felhasználás csökkenésével - a kisebb jódozott sófogyasztás miatt - azonban jelzések érkeztek a pajzsmirigy alulmúködésében tapasztalt zavarokról.

A jód konyhasóval történő bevitelét egy keményítő-származékba zárt jódra kidolgozott szabadalom révén sütőipari termékkel (zsemlékkel) megkísérelték kiváltani, de a sikeres árusítás dacára a projekt nem folyatódott.

A daganatos betegségek megelőzéséhez, kockázatuk csökkentéséhez nem lehet olyan egységes szempontokkal operáló programot kialakítani, mint a szív- és érrendszeri betegségeknél. Leginkább a táplálkozással összefüggő, az emésztőcső (vékony- és vastagbél) gyulladásos és rákos megbetegedésének megelőzésére, a kockázatok csökkentésére lehetséges vitaminokban és antioxidánsokban gazdag élelmiszerek fogyasztását ajánlani.

A leginkább elfogadott és viszonylag jól mérhető javulást a kalcium-tartalmú élelem fogyasztásával lehetett bizonyítani: a kalciumot tartalmazó tejtermékekkel csökkent a csontritkulás kockázata. A Magyar Tejgazdasági Kísérleti Intézet munkatársai, elsősorban Szakály Sándor professzor már régen felismerték és hirdették, hogy a tejtermékek élelmezési funkciói mellett egyre nagyobb jelentősége van az egészségre gyakorolt jótékony hatásuknak (SZAKÁLY, 1981). Idősebb korban, amikor a csontritkulás veszélye már közeli, orvosi előírásra és receptekre D3-vitamin pasztillákkal együtt sokan fogyasztanak rendszeresen citro-kalciumot, vagy más szerves vegyületekkel gyorsabban oldódó származékot.

\subsection{Testedzés, fizikai aktivitás - Training, Physical Activity}

A rendszeres testedzést végzők, de főleg a sportolók számára lényeges feladat a funkcionális élelmiszerek ismerete. A rendszeres testmozgás felgyorsítja az anyagcsere-folyamatokat, így fokozottan igényli a biológiailag aktív anyagok jelenlétét, katalitikus hatását. A testedzés hatására a tartalék-tápanyagok (szénhidrátok, zsírok) mobilizálódnak és elégetésükhöz szükség van az oxidációs-redukciós (redox) folyamatokban résztvevő mikroelemekre, többféle ásványi anyagot tartalmazó funkcionális élelmiszerekre (BIACS, 2002). A Debreceni Egyetem Gazdaságtudományi Karának Marketing és Kereskedelem Intézete által végzett felmérés szerint az egészségesebbnek vélt táplálkozásra történő áttérés nagymértékben függ az élelmiszer-fogyasztói magatartástól, mely jelenleg inkább csak az un. felkészülési szakaszban van (közepes változtatási hajlandóság), bár az áttérésben a megkérdezett nők előrébb jártak a férfiaknál (SOÓS et al., 2016).

\section{KöVETKEZTETÉSEK ÉS JAVASLATOK - CONCLUSIONS AND SugGeSTIONS}

Az egészségtudatos fogyasztói magatartás növekedésével előtérbe került az élelmiszerek egészségőrző szerepe. A szervezet vitaminokkal és ásványi anyagokkal való ellátottsága érdekében keresetté váltak a funkcionális élelmiszerek. A fogyasztók abban bíznak, hogy a táplálkozási útmutatók követésével a funkcionális élelmiszereknek nemcsak egészségőrző, hanem betegség-megelőző szerepük is lehet. 


\section{5. ÖSSZEFOGLALÁs - SUMMARY}

A funkcionális élelmiszerek a különleges (speciális) élelmiszerek közé tartoznak, melyeknek a tápértéken és élvezeti értéken kívül még egészségvédő hatást is tulajdonítanak. Az utóbbi évtizedben új élelmiszerek készültek a krónikus szív- és érrendszeri, daganatos betegségek kockázatának csökkentése céljából. A funkcionális élelmiszerek olyan hagyományos, minden piacon megtalálható termékek, melyeket a jobb egészségvédő hatás érdekében módosítottak. Magyarországon az élelmiszereket vásárlók 16\%-a választ egészségtudatosan, a táplálkozási útmutatókat követve. Legtöbben a tejtermékeket keresik, mert kalcium-tartalmuk révén csökkenthetik a csontritkulást, melynek előfordulása idősebb korban már egyre gyakoribb. Utóbbi években megnőtt az érdeklődés a gyümölcsök és zöldségek iránt, melyek jelentős antioxidáns-kapacitással rendelkeznek. A biológiailag aktív anyagok (vitaminok, ásványi anyagok, antioxidánsok) rendkívül eltérő mértékben halmozódhatnak fel az általunk ismert és termesztett növényekben, a tenyésztett állatokban, vagy a hasznos mikroorganizmusok sejttömegében. Intenzív gazdálkodásban a növény gyorsabban növekszik, több termést ad egységnyi területen, de kevesebb biológiailag aktív anyagot tartalmaz. Emiatt a belőlük előállított élelmiszereket mesterségesen kell kiegészíteni, dúsítani. Felmérések szerint az így készített élelmiszerek piaca nagyon jelentős és gyorsan növekvő, mert a rendszeresen sportolók, testépítők és nagyobb fizikai aktivitásra képes testedzők is érdeklődést mutatnak az egészséges táplálkozást biztosító élelmiszerek fogyasztására.

\section{IRODALOMJEGYZÉK - REFERENCES}

Biacs P.: A funkcionális élelmiszerek jelentősége a táplálkozásban. Magyar Sporttudományi Szemle. 2002. 2 27-29.

Biacs P.: A paprika gazdasági jelentősége a táplálkozásban és az iparban. Étkezési és füszer-paprika termesztése (Szerk.: Zatykó L. - Márkus F.) Mezőgazdasági Kiadó, Budapest, 2006. 216-219.

Biacs P. - Szántó Gyné.: Élelmiszeripari technológiák és az élelmiszerek vitamintartalma. Élelmezési ipar. 1985. 39 (5) 167-169.

Hajós Gy. - Biacs P.: Heart Healthy Nutrition in Hungary. Euro Food Chem X. (Szerk.: Lásztity R.) Budapest, 1999. 577580.

Soós M. - Kovács B. - Szakály Z.: A viselkedésváltozás szintjei a testtömeg-menedzselés folyamatában Élelmiszerfogyasztás és fizikai aktivitás. Táplálkozásmarketing. 2016. 3 (2) 19-28.

Szakály S.: A pasztőrözött tej- és tejszínkészítmények gyártása. Ipari és táplálkozási jelentőség. Tejipari kézikönyv (Szerk.: Balatoni M. - Ketting F.) Mezőgazdasági Kiadó, Budapest, 1981. 305-306. 